\title{
Modern Pre-School Education from the Standpoint of Self-Worth Childhood
}

\author{
Rais F. Shaikhelislamov' ${ }^{1}$ Rezida K. Shaekhova ${ }^{2}$, Alma Zh. Murzalinova ${ }^{3}$ \\ Kazan (Volga region) Federal University, Kremlyovskaya St. 18, 420008 Kazan, Russia, shraisf@rambler.ru \\ Kazan (Volga region) Federal University, Kremlyovskaya St. 18, 420008 Kazan, Russia, galeeva44@yandex.ru \\ National Center of professional development "Orleu”, Amangeldy St. 61, 050012 Petropavlovsk, Kazakhstan, \\ info@orleu-edu.kz
}

\begin{abstract}
Relevance of the studied problem is due to the reforming of the Russia education system that have begun in according to which the pre-school system is the first stage of general education and in this regard at the stage of practical implementation of reforms there is a risk of self-worth loss as the preschool period of development of the foundations of human culture in specific children's activities. The purpose of the article is the theoretical justification of transition of childhood phenomenon from the information paradigm to the cultural-historical one, in refinement of "early childhood education" category in the context of the FSES, in disclosure of the idea of preschool self-worth. Leading approach to the theoretical justification of the author's position is a cultural-historical system-activity approach. During the research process there are emerged number of important results: revealed and systematized the conditions for ensuring the childhood self-worth in the process of transformation of the system of preschool education into the stage of general education; was conducted the theoretical study of the need to preserve the specificity of preschool age as a basis for the formation of a full-fledged personality. Overall results of the study can help to solve the problem of formation the state educational policy aimed at improving the social status of preschool children, and may also be useful for developers of teaching materials of vocational and further education in the field of early childhood education.
\end{abstract}

Keywords: preschool childhood, early childhood education, Federal State Educational Standard of preschool education, system-activity approach, self-worth of childhood. 


\section{Introduction}

The Ministry of Education and Science of the Russian Federation approved the Federal State Educational Standard of preschool education two years ago, it's importance cannot be overestimated (the order of the Ministry of Education of the Russian Federation № 1155, 2013). The originality of the new standard is that the document began to act in accordance with the new law "On Education in the Russian Federation", in which preschool education is considered as the first level of general education.

In contrast to the official interpretation of the category "education" the earlier understanding of education is associated with the creation of the "image of man" (Ozhegov, 1984) otherwise the individual who encompasses all human qualities, and as a social being - all the qualities of the person. From the above it follows that preschool education is creating an image of a person in the preschool years, in which the foundations of personal culture and way of life are predetermined in the individual. And the process of becoming a personal culture is through "the child has the wealth of human culture" (Davydov, 1996).

It should be noted that the culture in the context of pre-school education is not only already formed personal experience of people, but also their creativity, which develop during the process of diverse creative activities at all age levels and the possibility of determining the mental development of those who takes possession of this culture.

When children live the stage of the entry into the world of culture for sure enrich their potential by new opportunities for creative development. Not by chance modern pedagogical science considers children's development as a process of communion the child to the world and self-determination in it. Back in the 60s a number of fundamental researches raised the question of the need to include the cultural components in the core of preschool education content (Skatkin, 1967.) In the development of this line in 1970-1980 it was made a truly innovative step, the designed model of educational content, correlated with the structure of the socio-cultural experience of mankind. This content was offered to build on the four basic elements of socio-cultural experience, "the experience of cognitive activity, fixed in the form of its results - knowledge; experience of the known methods of activity, in the form of the ability to act on the model; experience of creative activity - in the form of making nonstandard decisions in problem situations; experience of emotional and value relationships - in the form of personal orientations" (Krajewski, 2005).

\section{Methodological Framework}

The conceptual framework of the new standard of preschool education is based on full consideration of methodological positions by classical pedagogical and psychological 
scientists V. V. Davydov (1996), L. S. Vygotsky (1926), M. N. Skatkin (1967), V. V. Krajewski (2005), and others. Of particular note is that the authors of the standard firstly included in the content of education "experience of creative activity". In this regard, it should mention V. V. Davydov (1996) who noted: "The experience of creative activity should not be one of the elements arranged in a row of total social experience, and the main and fundamental element on which can lean other elements (which are knowledge, skills, and man's relationship to the world). In this case, the training and education of children from the outset will be directed to the development of their personality" (Davydov, 1996). Indeed, if the "experience of creative activity", understood by modern authors as a key from the system-level model of preschool education, then, perhaps, "the experience of cognitive activity" understand not only as a set of knowledge, but rather as a creative search for new knowledge, the desire to understand the unknown world with the help of adults. If the "experience of well-known ways of life" could be perceived not only as "the ability to act on the model", but in the ability to rebuild these skills and samples where it is needed, it would provide a scientific methodological basis of formation of the creative personality. And "the experience of emotional and value orientations" could be considered from the point of view of the development, implementation and disclosure the basic in the human person - its creativity (Davydov, 1996).

All this would make understanding conditions of culture as a creative process. Namely in this form of culture development is the basis of mental growth of children.

In the same time, a child can learn all created by mankind only by work and effort of his own thought and imagination. The child should rediscover what is already written in the orbit of people's social experience to play some essential features of their creative research, which eventually led to the creation of the whole system of cultural objects.

In the context of the creative development of children it is necessary to distinguish between creativity as "open to others" and creation as a "discovery for themselves". In the first case civilization is updated with new technological inventions, works of art, scientific discoveries. In the second case on the foreground comes not objective but subjective novelty of creativity products (Kudryavtsev, 2007).

In the process of transforming the traditional system of preschool education in the first stage of general education cannot ignore the fact that entering the child into the human world is a continuous chain of "discoveries for themselves". The result of "discovering" is not only a creation of a new object, but a change in the child, the emergence of new ways of life, knowledge and skills. Otherwise, the "discovery for me" is largely "self-discovery", although often unconscious by the "discoverer". This is stated in the research of L. S. Vygotsky, who linked the creation with "the development of new forms of behaviour", their exploration and growth (Vygotsky, 1926).

In connection with the above it is of particular value the assertion that development of creative abilities should become a mean of familiarizing children to the fundamental principles of a culture that ensures the formation of a child's holistic system of universal 
human abilities and properties (categorical perception, meaningful experiences, the ability to navigate to the position of another person, arbitrariness, goal setting, etc.). The solution of this problem is feasible only in the conditions of scaffolding during the preschool years. "It is impossible to identify the fake depth of human creativity, remaining only within the established forms of its activities and adopted systems of training and education, as in other conditions of life and other systems of training and education, this potential may vary considerably. The purpose of scaffolding consists of deepening and widening" (Davydov, 1996).

\section{Results}

One of the important components of the theoretical foundation of the problem of preserving the specificity of the preschool is a statement about the need to develop a creative approach in working with children. Creativity is the most popular and effective means of training and education in the preschool period. This implies that preschool education should be mainly developing character. In this regard, one can cite a number of quite convincing arguments:

First, it puts a priority to provide the children by historically developed means of orientation in the own inner world and its changes in the construction of various social contacts with other people.

Secondly, in the process of pre-school education a child receives the first opportunity to unveil a social significance and personal meaning of the teaching as an activity aimed not only at acquiring a certain amount of knowledge and skills, but on self-empowerment, which tools are the last ones.

Third, in the process of pre-school education child learns ways of building own activities, not just implementation of the own activities and the author's position within this activity (Kudryavtsev, 2007).

It seems fair the assertion that all kinds of children's activities (games, imitative, cognitive, research, and others.) are public in their origin, content and form. Therefore, a child in the first stages of its development, is a social being. And "appropriation achievements of human culture by child is always activity character" (Davydov, 1996).

Activities are match to the interest of the child and carried out in a developing object-spatial environment. It's not just the playing environment, but also environment for the development of children's activities. None of them can fully develop only on the verbal level, is object-spatial environment. Organized environment can have a positive impact on the development of self-employment, self-learning ability, gives him confidence in his ability, let take the initiative, independence, establishing himself as an active subject.

Above it was said that education is a child introduction to the culture world at various stages of his life. Depending on the purpose identified different levels of education. Thus, 
if to comprehend purposes of the pre-school education, in the most general form it can be characterized as follows: preschool education is the first level of general education, the process of assigning a child of wealth of human culture, aimed at the formation of personality in the preschool years as the subject of children's activities, communication, the process of entering the child's personality in culture and society.

In this sense early childhood education cannot be achieved without an in-depth study of historical and cultural heritage of its people. The most valuable thing is that for centuries formed by the wisdom and culture of the people, should be part of the education system.

In today's economic conditions, changes in society that dictate "ideals" of mass culture, when samples of other countries culture are being actively implemented in life, world of our children, folklore, folk music, folk arts and crafts (painting, sculpture, graphics, drawing, design) should be reflected in the content of education, including preschool. The value of the study of cultural heritage of the people is that it is a crystallized world of genuine national culture and is a kind of spiritual bridge between contemporary culture and the origins of human civilization. "This is the past in the present, it is an alive tradition, always preserving the chain of succession of generations, nations, and epochs", which manifests generic essence of man (Yusov, 1975).

Harmonious perception of national culture can be based on a holistic view of the child. In other words, on what he can rely on in the ethnic and cultural orientations. The main idea of organizing such a perception of national culture is to overcome the contradiction between the target installation on a holistic perception and object fragmentation of educational content. Therefore, we should begin the work with the inclusion of certain elements of national culture in the content of pre-school education, and then, as more information is necessary to use the methods of its generalizations. The knowledge that gets children should contain all fundamentally important structural components, which reveal its substantive aspect. In this case, the acquired knowledge in order to create children's representations about national culture should be codified. The integrity of the national culture indicates on the minimum set of elements to be included in the educational process. Moreover, these elements are introduced not piecemeal and summative, but by conceptual synthesis, meaningful generalization and systematization (Tunickov, 1994).

To build education and training in isolation from the national culture means to consider future generations "without family and tribe". From the above it follows that the system of preschool education must be inherent the character of national education, which involves the need to implement a part of the educational program, formed by members of educational relations, tasks of education of the citizen and patriot who know and love their homeland, people, language, the implementation of which cannot be without a deep study of historical and cultural heritage of the people. National culture is an area for development and self-development. Child can fully take the initiative, initiative and creativity living the childhood in the orbit of the national culture. 
Studies during recent years, both in our country and abroad, show this pattern: the earlier a child join in the modern world to the bright colourful folk art, the faster forms his creative thinking as a basis for the development of a creative personality.

Traditional folk art of the most familiar and close to the children, because of its visual-shaped specifics it is often more affordable to the child perception, rather than professional. Immediacy, colourful, decorative means of expression of folk art close to the inner world of children, relevant to the features of their creative work. It is easy to find many similarities in the work of craftsmen and children. And here and there the world is perceived in a special joy, major, and as joyful and festive embodied in their works.

The inclusion of national culture in practice into pre-school education should be carried out through the use of such potential means as language, children's literature, history, music, art, theatre, folklore and folk songs, dances, games, etc.

Development of creative abilities of children is impossible without learning the basis of the surrounding cultural environment, "immersion" of the individual in to the treasury of national culture, deep penetration in its aesthetic, moral, essential meaning, mastery of its expressive means. In this case, the person not only learns and reproduces the experience of previous generations, but also contributes to its development. Personality thus acts as a subject of national culture, a member of the cultural-historical process.

Formation of system knowledge of national culture in terms of the educational process is one of the most important factors in stimulating the development of new educational policy. From the above it can be concluded that the national character of education provides the development of cognitive interest in acquaintance with the nature of native land, history, architecture and culture. "The development of national culture and spirituality of its people, its culture enrichment by people living together, the orientation of the child to the culture as value will enable him to understand later the world culture. Only such a broad view on the culture of their own people, the perception in the context of its broader cultural processes can form the basis of formation and development of the creative personality, enabling it to not just passively contemplate the national culture, and make it their own individual contributions included in creating culture process" (Zhirkov, 1993).

In this sense preschool education is the universal form of not only development, but also self-development of the child (Kudryavtsev, 2007; Asmolov, 2002), which meaning and significance is not to accelerate the development but its enrichment with maximum use of all the capabilities of this period of life, as well as activity-development of social and historical experience of mankind and activity-uptake of social and historical experience of mankind, including the experience of peoples living together. Child's development in the in the preschool age should not be considered as a background or the fact of educational activity, but as the main problem, the main point of making every effort by the teacher who perceives childhood as a value period of human development. 


\section{Discussions}

We support the view according to which the self-worth of childhood in the new standard of preschool education is considered as a significant period of life because of what is happening with your child now, and not the fact that this period is a preparation for the next stage of life. In this regard, we should overcome the stereotype according to which pre-school stage is only an auxiliary character. It is obvious at first glance statement have not received due recognition in the recently enacted early childhood education programs. This point of view has penetrated deeply into the practice of general education and preschool institutions and was picked up by their parents, for whom the preschool period, as it was already mentioned, appears as a preparatory stage for school.

It should be noted that as opposed to this point as the basic characteristics of the preschool period of development are due to age stages of ontogeny personal manifestations of children embodied in the specific identity, in actions, deeds, assessments of reality, in the characteristic external behavioural patterns, i.e., that is a sign of a generalized childhood factor in the process of formation and, consequently, the success of development in general. Wherein physiological characteristics make up substantial foundation concepts. Its practical reflection and life meaning these features (in particular, intense pace of physical development, imitation, sensorimotor need, heightened emotionality, suggestibility, susceptibility, vulnerability, lack of morphological and functional maturity of the organs and systems, mobility of nervous processes, insufficient development of the arbitrariness of all mental processes, self-control) found in the implementation of educational activities, as well as in a variety of forms of children's subculture (Likhachev, 1979).

The modern system of education have to give the right to a modern child for full, childhood development, by definition V. V. Davydov (1996). Childhood differs by deployed and clear differentiation of its constituent ages - infancy, early age, preschool age, younger school age. During these periods the child lives special and responsible, one-piece and single piece of a life: from laying the foundation of the universal properties that make a man a man, up to the building the "first floor" of the human person.

In this logic, it is important to avoid conflicting interpretations between the position of the Law "On Education in the Russian Federation" and the Federal state educational standards of preschool education.

As you know, "education is a single purposeful process of education and training, which is socially significant boon and implemented for the benefit of the individual, family, society and the state" (Federal Law "On Education in Russian Federation")

At the same time, the Federal standard of preschool education gives priority to the principle of "support the diversity of childhood; preserving the uniqueness and self-worth of childhood as an important stage in the overall development of man, the self-worth of childhood is understanding (consideration) of childhood as a stage of life meaningful by itself, without any conditions; significant by what is happening with the child now, 
and not the fact that this period is the period of preparation for the next one" (order of the Ministry of Education of the Russian Federation № 1155, 2013).

In accordance with the adopted by developers the Federal standard of preschool education the ideology of preschool childhood is seen in the value system of coordinates of dignity culture, and not just the culture of utility. In this coordinate system, the child's is being valued, and do not assess, childhood is a period of self-valuable, and preschool education serves as an institution of socialization and individualization.

We stand in solidarity with the head of the Working Group, Director of the Federal Institute for Educational Development A. G. Asmolov (2002) in his speeches proves that on the basis of the standard laid cultural-historical methodology of developing systems, according to which the criterion of progress of various systems is the variability of growth occurring in these system elements. In the context of this methodology, education acts as a key mechanism to support a variety of systems. Unlike other standards the FSES PE is not a basis for the assessment of regulatory compliance to the results of the development of basic education programs. Development of educational programs of the pre-school education should not be accompanied by an intermediate and final certification of graduates in the final stages of pre-school education. Hence a key principle of the standard is the support of child diversity and the right to expression and the development of his personality.

There is reason to hope that the standard of preschool education will correct those deficiencies that have developed in this area over the past few years. Thirty years ago A. V. Zaporozhets (1996) warned against the intensification of pre-school education, which he called "artificial acceleration of child development". Today, the ideas of one of the largest domestic psychologists are relevant as ever.

Central psycho didactic technology of preschool education standard is a developing child's interaction with adults and peers and not just one-sided impact on the child. Standards do not allow to the transfer educational-disciplinary model of education on a child's life. The child in the preschool age is a person who always playing, so training should be a part of a child's life through the gates of children's play.

Date results of researches suggest that early forced preparation children for school has a negative impact on their mental and physical development, and in the long run turns fast fading interest to school by the first grade. Reluctance and inability of children to study only reinforces by it. This blocks the personal growth of the child and as a result is the inability to properly integrate into school life. Such a flippant attitude to pre-school age, according to V. I. Slobodchikov, may turn out to children in the best case irretrievably lost opportunities, and at worst - just follow the deformation of logic ontogeny (Slobodchikov, 1991).

Specificity of pre-school education is determined by the recognition of the self-worth value of this period in the children lives, taking into account the special educational needs of individual categories, including children with disabilities, of paramount importance 
the formation of a common culture; involves providing emotional well-being for every child, creating conditions for the development of their social, moral, aesthetic, intellectual, physical qualities, initiative, independence and responsibility and, therefore, offering a wide selection of content of their education, specifically children's activities (gaming, cognitive research, visual, perception of literature and folklore, and others).

\section{Conclusion}

At the present stage the level of pre-school education is regarded as one of the major educational provision. By its potential substantial capacity it is not inferior to any of the following and sets the foundation of the prerequisites for further schooling. Targets defined by new standard of preschool education are stand as the bases to ensure the continuity of pre-school and primary education. An important means of self-worth childhood in new conditions is a highly skilled management and appropriate staff of preschool institutions. We should create a management system of preschool education, aimed at the development of individuality, originality, uniqueness of the child. This system has to be able to realize self-worth of childhood, to ensure the variability and diversity of educational content and organizational forms of pre-school education, the possibility of the formation of various kinds of educational programs taking into account the abilities and the special educational needs of particular groups of children, including with disabilities.

The process of modernization of pre-school education related to its inclusion in general education preschool education allows a fundamentally new way to treat this age period of the child's personality only if the pre-school organizations will be provided with educational and methodical complex of new generation that allows changing the mentality of practitioners.

Certainly we hope to create an entirely new system of information and methodological support of teachers and make an effort to create domain-developing environment in accordance with the new educational objectives. Under these conditions, it will be possible to create a complete creatively developed environment and implement the principle of self-worth childhood.

\section{Acknowledgments}

The work is performed according to the Russian Government Program of Competitive Growth of Kazan Federal University. 


\section{References}

Asmolov, A. G. (2002). Personality Psychology: Principles of general psychological analysis. Moscow: The meaning of IC Academy.

Davydov, V. V. (1996). The theory of developmental education. Moscow: INTOR.

Federal Law "On Education in the Russian Federation" dated December 29 2012, No. 273.

Krajewski, V. V. (2001). The content of education. Moscow.

Kudryavtsev, V. T. (2007). Paths: Conceptual framework of the project of developmental preschool education. Moscow: Ventana Graf.

Likhachev, B. T. (1979). Common problems of education in schools. Moscow.

Ozhegov, S. I. (1984). Dictionary of the Russian language. Moscow.

Skatkin, M. N. (1967). What you need to know about the problems of modern didactics. Application to the Journal Education, 1, 14.

Slobodchikov, V. I. (1991). Age category in psychology and pedagogy. Questions of psychology, 2, 43. The Order of the Russian Ministry from October 17 2013, No. 1155 "On approval of the federal educational standards of preschool education" (Registered in the Ministry of Justice of Russia November 14 2013, No. 30384).

Tyunnikov, Y. S., Hasanov, G. F., Kharisov, F. F. (1994). National identity: the nature and principles of formation. Kazan.

Vygotsky, L. S. (2007). Educational Psychology. Education from the standpoint of age values education. Preschool education, 4, 25.

Yusov, B. P. (1975). On the problem of the relationship of arts in children's artistic development. Moscow.

Zaporozhets, A. V. (1996). Development of voluntary movements. Moscow.

Zhirkov, E. P. (1993). National School: concept and technology development. Moscow. 


\title{
Modernus ikimokyklinis ugdymas vaikystès savivertės požiūriu
}

\author{
Rais F. Shaikhelislamov ${ }^{1}$, Rezida K. Shaekhova ${ }^{2}$, Alma Zh. Murzalinova ${ }^{3}$ \\ Kazanės universitetas, Kremlyovskaya g. 18, 420008 Kazanė, Rusija, shraisf@rambler.ru \\ Kazanès universitetas, Kremlyovskaya g. 18, 420008 Kazanė, Rusija, galeeva44@yandex.ru \\ Nacionalinis profesijos tobulinimo centras „Orleu“, Amangeldy g. 61, 050012 Petropavlovskas, Kazachstanas, \\ info@orleu-edu.kz
}

\section{Santrauka}

Nagrinejjamos problemos aktualumą rodo tai, kad Rusijos švietimo sistemos reforma prasidejo būtent nuo ikimokyklinio ugdymo. Todèl igyvendinant reformą kyla rizika sumenkinti vaikystès amžiaus tarpsnio reikšmingumą, ugdant humaniškos kultūros pagrindus specialiomis vaikų veiklomis.

Šio straipsnio tikslas yra atskleisti teorines prieigas, transformuojančias vaikystès fenomeno supratimą nuo informacinès paradigmos link kultūrinės-istorinės paradigmos, tobulinant „ankstyvojo ugdymo vaikystejje“ sampratą FSES kontekste, išryškinant ikimokyklinio ugdymo savivertès idejją. Straipsnio autorių teorinè prieiga grindžiama sisteminès veiklos kultūriniu-istoriniu požiūriu. Tyrimo metu gauti reikšmingi rezultatai: atskleistos ir susistemintos vaikystės savivertès užtikrinimo sąlygos, reformuojant ikimokyklinio ugdymo sistemą; atlikta teorinè studija, parodanti ikimokyklinio amžiaus vaikų specifiškumo išsaugojimo poreikį, ugdant visavertę asmenybę. Gauti tyrimo rezultatai padès formuoti švietimo politiką, gerinančią ikimokyklinio amžiaus vaikų socialinị statusą; taip pat bus naudingi ir kuriant didaktines priemones profesiniam ir tęstiniam tobulëjimui ankstyvosios vaikystès ugdymo srityje.

Esminiai žodžiai: ikimokyklinis ugdymas, ankstyvasis ugdymas, federaliniai ikimokyklinio ugdymo standartai, sisteminès veiklos požiūris, savivertè vaikystés saviverté.

Itteikta / Received 2015-05-26

Priimta / Accepted 2015-06-30 